\title{
Importance of dead wood resources for woodpeckers in coniferous stands of the Białowieża Forest
}

\author{
DOROTA CZESZCZEWIK, WIESŁAW WALANKIEWICZ, \\ CEZARY MITRUS, TOMASZ TUMIEL, TOMASZ STAŃSKI, \\ MUSTAPHA SAHEL and GRZEGORZ BEDNARCZYK
}

\begin{abstract}
Summary
Many woodpecker species are known to be sensitive to the removal of dead wood. In 1999-2001 and 2007-2009 woodpeckers and dead wood abundance were studied in coniferous stands of the Białowieża Forest, Poland. Transects (3.9-6 km long) were established in three zones of different types of management: 1 ) primeval, unmanaged stands (BNP); 2) partially managed nature reserve (RES); 3) heavily managed stands (MAN). Woodpeckers were counted along transects three times per season, and tree stand measurements (number of standing and fallen trees, diameter at breast height, volume of fallen logs) were made once every three years. Woodpecker indices were highest in BNP and lowest in RES in both three-year study periods. The highest number of species (seven) was recorded in RES. Indices of four woodpeckers including two focal species (Three-toed Woodpecker Picoides tridactylus and White-backed Woodpecker Dendrocopos leucotos) were dependent on the basal area of dead standing trees. The same relation was found for the whole woodpecker assemblage. The highest indices were recorded in BNP, where the highest density of dead standing trees was recorded, and the lowest in the MAN transect with the lowest density of dead trees. However in the RES plot the amount of dead wood was much lower than in the national park. We recommend that the management regulations in Polish nature reserves be changed. In coniferous reserves, it would be best to leave at least $2 \mathrm{~m}^{2} \mathrm{ha}^{-1}$ (basal area) of freshly killed spruce Picea sp. after each bark beetle outbreak.
\end{abstract}

\section{Introduction}

Dead wood is a very important element of forest ecosystems; it was abundant in the past in forests but now is generally very scarce. In primeval forests, standing and fallen dead trees provide food and shelter for many rare and threatened species, including vertebrates as well as invertebrates (Whiles and Grubaugh 1996, Bobiec et al. 2005, Walankiewicz et al. 2002). The abundance of dead wood also contributes to biodiversity (Ohlson et al. 1997) and is an important key element outside, as well as within, traditional protected areas (Jönsson and Jonsson 2007). Many woodpecker species are associated with dead trees which are used for foraging, roosting or nesting. A positive correlation between the amount of dead wood and woodpecker indices in deciduous stands of the Białowieża Forest was shown by Walankiewicz et al. (2002). Among the species most sensitive to the removal of dead wood in the forest are two of the rarest European species, Three-toed Woodpecker Picoides tridactylus and White-backed Woodpecker Dendrocopos leucotos (Bütler et al. 2004, Czeszczewik and Walankiewicz 2006, Roberge et al. 2008). Dead and dying trees (notably Norway spruce Picea abies in Europe) are usually removed from managed forests as a means of reducing pest species. Obviously, these practices lead to a decrease in 
forest biodiversity causing conflicts between forest conservation and forestry interests (Wesołowski 2005).

In the Białowieża Forest which served as a protected hunting area for centuries, heavy logging started late, i.e. during the First World War and is still ongoing. Only c.16\% of the forest is protected as a national park while the rest, including nature reserves, is managed by the state forestry service and quotas of logged timber were as high as $150,000 \mathrm{~m}^{3}$ year $^{-2}$ (Wesołowski 2005). Although the intensity of management is lower in nature reserves, during sanitary cutting due to outbreaks of spruce bark beetle Ips typographus a lot of infested spruce trees were removed. As a result, the amount of dead wood in the nature reserves is much lower than in the strictly protected stands of the Białowieża National Park (Bobiec 2002, Walankiewicz et al. 2002). Despite long-term protection, in some reserves lasting even for 90 years, old-growth stands, large snags and fallen logs are present only rarely. Such selective cutting and removal of dead spruce in managed stands and nature reserves has led to habitat destruction for the Three-toed Woodpecker. Removal of infected spruce from whole nature reserve stands was allowed in the Białowieża Forest until spring 2008.

Our goal was to assess the impact of dead wood resources and type of forest management with three levels of protection, national park, nature reserve and managed stands, on woodpecker communities in coniferous stands of lowland forest. We also make recommendations on management of dead wood resources in forests, especially in Polish nature reserves to improve habitat quality for woodpeckers.

\section{Study area and methods}

The study was conducted during two three-year periods (1999-2001 and 2007-2009) in the Białowieża Forest, north-east Poland. Białowieża Forest $\left(52^{\circ} 29^{\prime}-52^{\circ} 57^{\prime} \mathrm{N}, 23^{\circ} 31^{\prime}-24^{\circ} 21^{\prime} \mathrm{E}\right)$ is located on the border between Poland and Belarus and covers c.1,500 km in total. This forest was protected for centuries as a royal hunting area but its intensive exploitation started during the First World War. The whole Polish section of the Białowieża Forest is a Natura 2000 site. Its central part $\left(47.47 \mathrm{~km}^{2}\right)$ is very well preserved and protected by law since 1921 as the Białowieża National Park, which was enlarged to $105.2 \mathrm{~km}^{2}$ in 1996. Most of the national park tree stands and some small fragments outside the park have a primeval origin. Tree stands are multispecies, multilayer and uneven-aged, with large amounts of standing and fallen dead wood. The most common type of forest is lime-hornbeam-oak stands dominated by hornbeam Carpinus betulus, lime Tilia cordata, oak Quercus robur, Norway spruce, Norway maple Acer platanoides and some other species. River valleys and some depressions are covered with ash-alder stands (with ash Fraxinus excelsior, alder Alnus glutinosa and spruce). Coniferous spruce-pine forests (with spruce and Scots pine Pinus sylvestris and some admixture of broad-leaved trees) are located on sandy soils (Faliński 1986).

Most (c.82\%) of the Polish part of the Białowieża Forest is managed by the State Forestry Service. Within this area, 21 nature reserves $\left(\right.$ c.120 $\left.\mathrm{km}^{2}\right)$ are located - about $20 \%$ of the total forest area. In nature reserves outside Białowieża National Park, some management activity is allowed e.g. sanitary cutting and planting new trees. Removal of all infested and susceptible spruce was allowed according to the law in most nature reserves until March 2008.

Three transects were set out in coniferous stands, dominated by Norway spruce and Scots pine and representative of various types of forest management i.e. national park, nature reserve and managed stands (Figure 1 ):

- BNP (3.9 km) - in primeval stands of the Białowieża National Park. The transect consisted of two sections (due to a lack of a sufficiently long single stretch in one site) along forest roads. Spruce-pine forest with an admixture of oak, birch Betula spp. and hornbeam. It was an old-growth stand with the oldest trees exceeding 200 years in age. No management, except for removal of fallen trees from the road. 


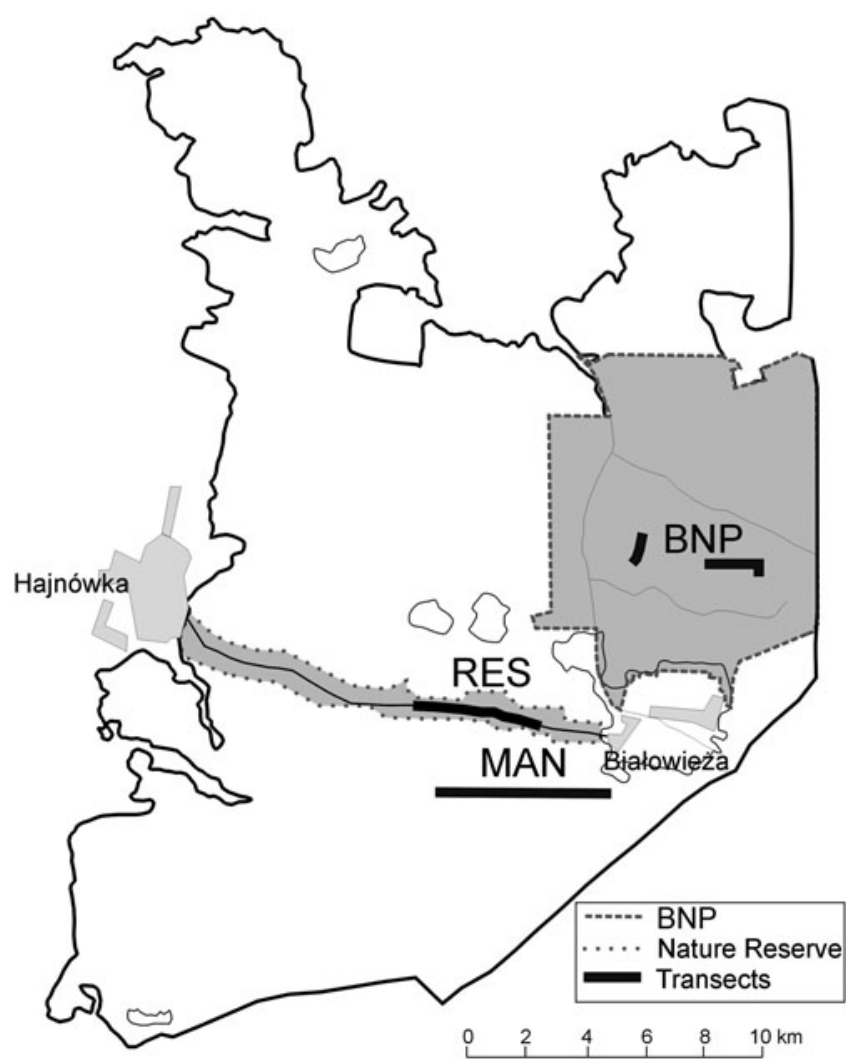

Figure 1. Location of transects in the Białowieża Forest.

- RES $(5.5 \mathrm{~km})$ - in the nature reserve, along the Hajnówka-Białowieża road. Spruce-pine forest (old and middle age) with an admixture of hornbeam, oak and aspen Populus tremula. The age of the forest was c.80-150 years. Until the beginning of 2008 some so-called "sanitary cutting" was done there (mainly removal of infected and dead trees).

- MAN (6 km) - in managed stands, along the Jagielloński forest road. Spruce-pine forest of mixed age covered this part of the forest, with some admixture of birch, oak and hornbeam. This forest was about $40-80$ years old and it represents most of the managed coniferous tree stands in Białowieża Forest. Typical management was conducted here (clear-cuts and spruce-pine fenced plantations).

Woodpeckers were counted along transects using the bike-transect method described in detail by Walankiewicz et al. (2002). Three times per season (31 March-22 May), in the early morning (o4h30-07h45), all woodpeckers seen or heard drumming or calling were recorded. Transects were conducted at an average speed of $c .5 .5 \mathrm{~km} \mathrm{~h}^{-1}$. For each species, the maximum number of records from one of the three counts was included in the analysis in each season (as an index we used the mean number of woodpeckers recorded per $1 \mathrm{~km}$ ). For other analyses, the average values of the annual maxima from the three consecutive years were used.

Along all transects, dead wood resources were measured twice (in 2000-2001 and 2008-2009). All standing and fallen trees (logs) were recorded and measured within rectangular (20 x $25 \mathrm{~m})$ plots evenly distributed along both sides of the transect (2O plots in BNP, 28 in RES, 31 in MAN). 
Each sample plot was located $20 \mathrm{~m}$ away from the road so they could be considered as representative of the forest structure away from roads. Diameter at breast height (DBH) for all standing trees, their condition (alive or dead), and species were recorded. For each fallen log, the length of the main trunk and the diameter at each end were also measured. Then, the volume of the fallen logs was calculated using the cut-cone formula. The basal area of standing trees was calculated using the circumference of the tree trunk section at breast height. For all calculations, only trees with at least $11 \mathrm{~cm}$ DBH were included. For comparisons, average values recalculated for each plot per hectare were used. Therefore, the sample size for each transect was equal to the number of the measured plots i.e. 20 (BNP), 28 (RES) and 31 (MAN). The effects of basal area of dead and live trees, transect location, and time of study on the numbers of woodpeckers were analysed with generalised linear mixed models (GLMM) using restricted maximum likelihood. Generalised linear models (GLZ) with Poisson distribution and logarithmic link function were constructed to analyse the relationships between transect location and study period on characteristics of tree stands. Statistical analyses were performed using Statistica ${ }^{\circledR}$ version 9.o.

\section{Results}

Woodpeckers

The highest number of species (seven) was observed in RES and the lowest in the MAN transects (four species in 1999-2001, and only two - Great Spotted Woodpecker Dendrocopos major and Black Woodpecker Dryocopus martius in 2007-2009). In BNP, five species of woodpeckers were recorded during the study (Table 1 ) and no differences in the number of woodpecker species between two three-year study periods were recorded on all study plots $\left(\chi^{2}=0.71, \mathrm{df}=2, P=0.70\right)$.

The average total indices of all woodpeckers combined (and without the Great Spotted Woodpecker) increased on all transects in 2007-2009 compared to 1999-2001, and their numbers

Table 1. Indices of woodpeckers (individuals $\mathrm{km}^{-1}$ ) on three transects during six years of study.

\begin{tabular}{|c|c|c|c|c|c|c|c|}
\hline \multirow[b]{2}{*}{ Species } & \multirow[b]{2}{*}{ Transect } & \multicolumn{6}{|c|}{ Year of study } \\
\hline & & 1999 & 2000 & 2001 & 2007 & 2008 & 2009 \\
\hline \multirow[t]{3}{*}{ Dendrocopos major } & $\mathrm{BNP}$ & 6.7 & 5.1 & $3 \cdot 3$ & 5.6 & $5 \cdot 4$ & 5.1 \\
\hline & RES & 2.2 & 2.9 & $3 \cdot 3$ & $4 \cdot 7$ & 2.4 & $4 \cdot 4$ \\
\hline & MAN & 2.7 & 2.5 & 1.7 & $4 \cdot 5$ & 2.8 & 2.8 \\
\hline \multirow[t]{3}{*}{ Dendrocopos medius } & BNP & 0.5 & 0.3 & o & 0.5 & o & 0.3 \\
\hline & RES & 0.5 & 0.4 & o & 0.4 & 0.2 & 0.2 \\
\hline & MAN & 0.2 & o & o & o & o & o \\
\hline \multirow[t]{3}{*}{ Dendrocopos leucotos } & BNP & 0.3 & 0.3 & o & 0.8 & 0.3 & o \\
\hline & RES & 0.2 & o & o & 0.2 & o & 0.2 \\
\hline & MAN & o & o & o & o & o & o \\
\hline \multirow[t]{3}{*}{ Dendrocopos minor } & BNP & o & o & o & o & o & o \\
\hline & RES & o & o & o & 0.2 & 0.2 & o \\
\hline & MAN & o & o & o & $\mathrm{O}$ & $\mathrm{o}$ & o \\
\hline \multirow[t]{3}{*}{ Dryocopus martius } & $\mathrm{BNP}$ & 1.0 & 1.0 & 1.3 & 1.0 & 0.8 & 1.3 \\
\hline & RES & 0.4 & 0.5 & 0.4 & 0.4 & 0.2 & 0.9 \\
\hline & MAN & 0.5 & 0.5 & 0.5 & 0.5 & 0.7 & 0.2 \\
\hline \multirow[t]{3}{*}{ Picoides tridactylus } & $\mathrm{BNP}$ & 1.5 & 1.5 & 0.8 & 2.1 & 0.5 & 1.5 \\
\hline & RES & 0.2 & o & o & 0.4 & 0.4 & 0.9 \\
\hline & MAN & 0.5 & 0.2 & o & o & o & o \\
\hline \multirow[t]{3}{*}{ Picus canus } & BNP & o & o & o & $\mathrm{O}$ & $\mathrm{o}$ & o \\
\hline & RES & 0.5 & o & 0.2 & o & o & 0.2 \\
\hline & MAN & o & o & o & o & $\mathrm{o}$ & o \\
\hline
\end{tabular}


depended on the effects of basal area of snags but not on the basal area of live trees, study period and location of transect (Table 2). The highest indices were recorded in the BNP in both threeyear study periods (Table 1 ), where the highest density of dead standing trees was recorded and the lowest in the MAN transect in the second study period with the lowest density of dead trees (Table 3).

The Great Spotted Woodpecker was the most numerous species. Its density was dependent on the basal area of snags but not on the basal area of live trees, the study period and location of transect (Table 2), and no interaction between study period and location was recorded. The same pattern was observed in the Black Woodpecker, Three-toed Woodpecker and White-backed Woodpecker where their density was dependent on the basal area of snags but not on the basal area of live trees, the study period, or location of transect (Table 2). In the case of the Middle Spotted Woodpecker Dendrocopos medius and Grey-headed Woodpecker Picus canus no effect of any analysed factors was found (Table 2). Only Lesser Spotted Woodpecker Dendrocopos minor density depended on transect location, but not on the basal area of snags or study period, and interaction between study period and location was recorded (Table 2). In comparison to 19992001, indices of the other species combined, except for Great Spotted Woodpecker in 2007-2009, decreased only in the transect MAN (Figure 2), where density of snags was the lowest (Table 3).

\section{Dead wood resources}

The basal area of standing dead trees was dependent on the study area (Wald's statistic $=532.7$, $P<0.001$ ) and on study period (Wald's statistic $=19.63, P<0.001$ ). The same relation was observed in the case of the volume of fallen wood (Wald's statistic $=146.5, P<0.001$ and Wald's statistic $=27.6, P<0.01$, respectively). The greatest amount of dead wood (standing trees and fallen wood) was found in BNP while the lowest was in both: MAN (both periods) and RES (first study period; Table 3).

\section{Discussion}

Line transect methods are used relatively often for the estimation of the abundance of common breeding birds in forest landscapes (Solonen and Jokimäki 2010). The bike-transect method, a variant of the line-transect method, if used for woodpeckers only, is relatively easy to conduct in the field but the observers should be very well trained in distinguishing the calls and drummings of all woodpecker species (Walankiewicz et al. 2002, 2009, 2011). Results obtained by this method do not provide information on the number of territories because both sexes of woodpeckers can drum or call. However, results can be comparable between different plots or years using indices (recorded woodpeckers per kilometre). The bike-transect method was recommended as a fast inventory method for some woodpeckers in lowland stands (Czeszczewik et al. 2009, Walankiewicz et al. 2009).

The highest number of species (seven) was observed on the RES transect while in BNP only five species were found. We might expect the greatest diversity in BNP due to the highest amount of dead wood, but no Lesser Spotted or Grey-headed Woodpeckers were recorded there. Both species clearly prefer deciduous stands, which explains why they are rather sparsely distributed in the national park (Wesołowski et al. 2003). Three of the five species recorded in BNP are typical of coniferous forests and all these species (Great Spotted, Black and Three-toed Woodpeckers) comprised the basis of the community. White-backed Woodpecker and Middle Spotted Woodpecker are more often associated with deciduous stands and were observed in BNP much less frequently (Wesołowski and Tomiałojć 1986). Transect MAN was the poorest in both numbers of species and density of woodpeckers. This could be related to forest structure and the small amount of dead wood recorded there. This transect also had the lowest rate of deciduous trees compared to BNP and RES (Table 3). Tree stands along the transect MAN represented typical coniferous stands managed by the forestry service in the Białowieża Forest. 
Table 2. Effects of basal area of dead and live trees, transect location and time of study on the numbers (indices $=$ individuals $\mathrm{km}^{-1}$ ) of woodpeckers (F-tests for linear mixed model fits); df: denominator degrees of freedom. Bold $P$-values indicate significant effects.

\begin{tabular}{|c|c|c|c|c|}
\hline Species & Variable and $\mathrm{R}^{2}$ & $\mathrm{df}$ & $F$ & $P$ \\
\hline \multirow[t]{5}{*}{ Dendrocopos major } & Basal area of dead trees & 12 & 19.37 & $<0.001$ \\
\hline & Basal area of live trees & 12 & 2.07 & 0.18 \\
\hline & Location of transect & 12 & 0.52 & 0.61 \\
\hline & Study period & 12 & 0.26 & 0.62 \\
\hline & $R^{2}=0.51$ & 12 & $4 \cdot 54$ & 0.01 \\
\hline \multirow[t]{5}{*}{ Dendrocopos medius } & Basal area of dead trees & 12 & 1.36 & 0.27 \\
\hline & Basal area of live trees & 12 & 1.08 & 0.32 \\
\hline & Location of transect & 12 & 1.86 & 0.20 \\
\hline & Study period & 12 & 0.00 & 0.95 \\
\hline & $R^{2}=0.06$ & 12 & 1.23 & 0.35 \\
\hline \multirow[t]{5}{*}{ Dendrocopos leucotos } & Basal area of dead trees & 12 & 6.64 & 0.02 \\
\hline & Basal area of live trees & 12 & 0.01 & 0.96 \\
\hline & Location of transect & 12 & 0.50 & 0.62 \\
\hline & Study period & 12 & 0.01 & 0.91 \\
\hline & $R^{2}=0.14$ & 12 & 1.53 & 0.25 \\
\hline \multirow[t]{5}{*}{ Dendrocopos minor } & Basal area of dead trees & 12 & 0.92 & 0.36 \\
\hline & Basal area of live trees & 12 & 4.53 & 0.06 \\
\hline & Study period & 12 & $5 \cdot 51$ & 0.02 \\
\hline & Location of transect $\mathrm{x}$ Study period & 12 & $3 \cdot 54$ & 0.08 \\
\hline & $R^{2}=0.47$ & 12 & 4.0 & 0.02 \\
\hline \multirow[t]{5}{*}{ Dryocopus martius } & Basal area of dead trees & 12 & 26.61 & $<0.001$ \\
\hline & Basal area of live trees & 12 & 0.01 & 0.96 \\
\hline & Location of transect & 12 & 1.07 & 0.37 \\
\hline & Study period & 12 & 0.30 & 0.59 \\
\hline & $R^{2}=0.58$ & 12 & 5.8 & 0.006 \\
\hline \multirow[t]{5}{*}{ Picoides tridactylus } & Basal area of dead trees & 12 & 31.48 & $<0.001$ \\
\hline & Basal area of live trees & 12 & 0.18 & 0.68 \\
\hline & Location of transect & 12 & 0.27 & 0.77 \\
\hline & Study period & 12 & 1.56 & 0.24 \\
\hline & $R^{2}=0.63$ & 12 & 6.75 & 0.003 \\
\hline \multirow[t]{5}{*}{ Picus canus } & Basal area of dead trees & 12 & 1.53 & 0.24 \\
\hline & Basal area of live trees & 12 & 3.71 & 0.08 \\
\hline & Location of transect & 12 & 1.70 & 0.22 \\
\hline & Study period & 12 & 1.00 & 0.34 \\
\hline & $\mathrm{R}^{2}=0.21$ & 12 & 1.93 & 0.16 \\
\hline \multirow[t]{5}{*}{ All woodpeckers } & Basal area of dead trees & 12 & 32.00 & $<0.001$ \\
\hline & Basal area of live trees & 12 & 0.73 & 0.41 \\
\hline & Location of transect & 12 & 1.01 & 0.39 \\
\hline & Study period & 12 & 0.00 & 0.96 \\
\hline & $R^{2}=0.66$ & 12 & 6.95 & 0.003 \\
\hline \multirow[t]{5}{*}{ All species but D. major } & Basal area of dead trees & 12 & 26.06 & $<0.001$ \\
\hline & Basal area of live trees & 12 & 0.05 & 0.83 \\
\hline & Location of transect & 12 & 0.94 & 0.42 \\
\hline & Study period & 12 & 0.57 & 0.46 \\
\hline & $R^{2}=0.58$ & 12 & $5 \cdot 7$ & 0.006 \\
\hline
\end{tabular}


Table 3. Habitat characteristicss on transects during two study periods. Mean and $( \pm)$ standard deviation are shown. Sample size in parentheses.

\begin{tabular}{|c|c|c|c|c|c|c|}
\hline \multirow[t]{2}{*}{ Years } & \multicolumn{3}{|l|}{$2000-2001$} & \multicolumn{3}{|l|}{ 2008-2009 } \\
\hline & $\mathrm{BNP}(20)$ & RES (28) & MAN (3I) & $\mathrm{BNP}(20)$ & RES (28) & MAN (3I) \\
\hline Density of live trees (trees $\mathrm{ha}^{-1}$ ) & $286.0 \pm 156.6$ & $354.3 \pm 96.0$ & $613.3 \pm 245.8$ & $303.0 \pm 126.4$ & $375.0 \pm 121.9$ & $722.7 \pm 303.7$ \\
\hline Basal area of live trees $\left(\mathrm{m}^{2} \mathrm{ha}^{-1}\right)$ & $25.8 \pm 14.5$ & $40.7 \pm 13.5$ & $38.7 \pm 12.5$ & $22.3 \pm 12.9$ & $33.6 \pm 12.0$ & $35.1 \pm 10.2$ \\
\hline Proportion of deciduous trees basal area (\%) & $21.3 \pm 20.6$ & $22.5 \pm 21.1$ & $13.8 \pm 15.6$ & $32.6 \pm 36.0$ & $28.7 \pm 19.9$ & $11.2 \pm 19.8$ \\
\hline Density of all snags (stems ha ${ }^{-1}$ ) & $71.0 \pm 66.0$ & $5.7 \pm 14.3$ & $13.5 \pm 20.3$ & $92.0 \pm 45.6$ & $10.7 \pm 22.1$ & $8.4 \pm 17.7$ \\
\hline Density of spruce snags (stems ha-1) & $102.0 \pm 57.3$ & $6.4 \pm 13.4$ & $14.0 \pm 23.0$ & $110.0 \pm 54.5$ & $16.4 \pm 21.1$ & $10.0 \pm 15.5$ \\
\hline Basal area of all snags $\left(\mathrm{m}^{2} \mathrm{ha}^{-1}\right)$ & $10.2 \pm 8.2$ & $0.4 \pm 1.1$ & $0.5 \pm 1.1$ & $13.8 \pm 8.1$ & $1.9 \pm 3.5$ & $0.2 \pm 0.5$ \\
\hline $\begin{array}{l}\text { Spruce snags basal area as } \\
\text { proportion of all snags (\%) }\end{array}$ & $51.4 \pm 40.0$ & $47.6 \pm 50.4$ & $45.6 \pm 48.2$ & $63.9 \pm 23.3$ & $32.1 \pm 46.4$ & $34.8 \pm 45.0$ \\
\hline Density of fallen logs $\left(\operatorname{logs} \mathrm{ha}^{-1}\right)$ & $115.0 \pm 103.0$ & $5.0 \pm 11.7$ & $16.0 \pm 21.3$ & $129.0 \pm 99.1$ & $11.4 \pm 14.8$ & $10.0 \pm 25.6$ \\
\hline Volume of fallen logs $\left(\mathrm{m}^{3} \mathrm{ha}^{-1}\right)$ & $72.9 \pm 65.4$ & $1.1 \pm 3.3$ & $2.7 \pm 5.0$ & $93.6 \pm 69.1$ & $11.5 \pm 25.6$ & $1.4 \pm 3.6$ \\
\hline
\end{tabular}




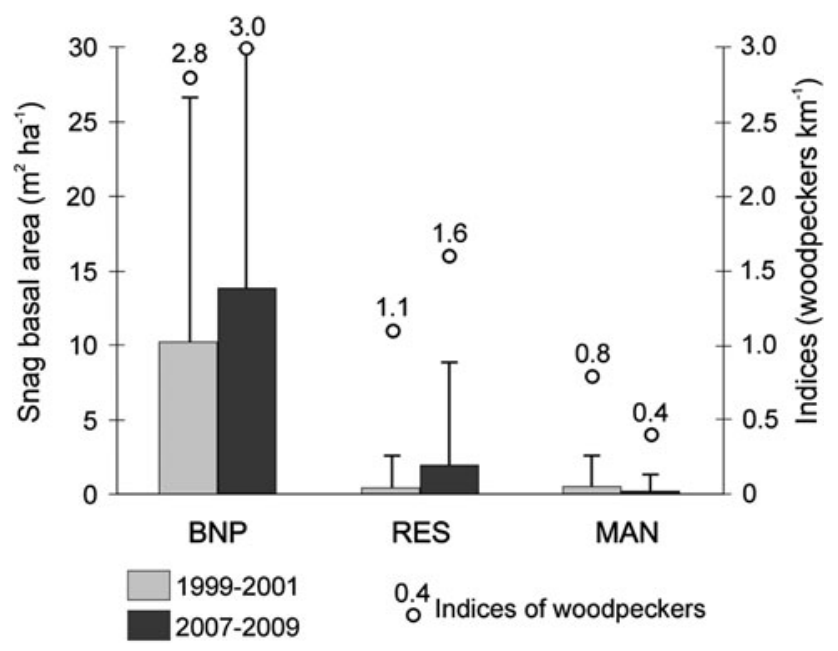

Figure 2. Average basal area of snags (bars; whiskers show standard deviations) and changes in woodpecker abundance (all but the Great Spotted Woodpecker) in two study periods.

The most common species in all study years and transects was the Great Spotted Woodpecker. It most often uses live trees for both nesting and foraging (e.g. Michalek and Miettinen 2003), though we also showed its relationship to dead trees. The mean density of Great Spotted Woodpecker obtained by a mapping method in 1999-2001 and 2007-2009 in coniferous stands of the Białowieża National Park was 1.5 pairs 10 ha $^{-1}$, while the other woodpecker species combined together had a mean density of 0.6 pair $10 \mathrm{ha}^{-1}$ (Wesołowski et al. 2002, 2006, 2010). Earlier, the Great Spotted Woodpecker in primeval coniferous stands of Białowieża National Park comprised $71 \%$ of the whole woodpecker assemblage (range 58-83; Wesołowski et al. 2002, 2006, 2010). Similarly in this study it comprised $65 \%$ of all woodpeckers (range $56-78$ ). This proportion was comparable to that in the RES transect (average $72 \%$, range 55-86) but in the most transformed stands of the MAN transect the proportion of the Great Spotted Woodpecker was even higher (average 82\%, range 70-94).

A positive correlation between woodpecker indices and density of snags also in deciduous stands of the Białowieża Forest has been found earlier. The total relative number of woodpeckers recorded in BNP was on average twice as high as in managed deciduous stands. Moreover three species, Three-toed, Black and White-backed Woodpeckers, foraged mostly on dead wood (Walankiewicz et al. 2002). This study also confirmed that the same three woodpeckers were the most associated with dead wood resources in coniferous stands.

In the first years of study, Three-toed and Middle Spotted Woodpeckers were rarely recorded on the transect MAN and we had no such records of these species in the last years of the study. Due to habitat preferences, Middle Spotted Woodpecker occurrence in spruce-pine forest was rather occasional, while the Three-toed Woodpecker is a typical species of coniferous stands. This latter species requires freshly dead and dying spruce for foraging (Bütler et al. 2004, Pechacek 2006). It is also considered as an indicator species in coniferous forests (e.g. Roberge and Angelstam 2006). In most of our studied transects, one-third to two-thirds of standing dead trees were spruces (Table 3 ) but in the transect MAN only a few dead trees per hectare were left. In the transect RES in the first study period (1999-2001) the Three-toed Woodpecker was only once recorded but in the second period (2007-2009), when a spruce bark beetle outbreak occurred, this woodpecker was regularly observed. This coincided with the prohibition of the removal of dead trees in nature reserves of the Białowieża Forest by the Polish Minister of Environment in March 2008. 
In the primeval stands of BNP density of dead spruces was always so high (5-12 times higher than in RES and MAN transects; Table 3) that even spruce bark beetle outbreaks did not result in much increase in the numbers of the Three-toed Woodpecker. In contrast, in the nature reserve (RES) or managed stands (MAN), the amount of dead wood was unusually small, and even a slight increase in snag density (a few snags per hectare) could have a positive effect on woodpecker indices. It was shown earlier that the probability of the presence of Three-toed Woodpeckers increased significantly when basal area of snags increased from 0.6 to $1.3 \mathrm{~m}^{2} \mathrm{ha}^{-1}$ in Switzerland and from 0.3 to $0.5 \mathrm{~m}^{2} \mathrm{ha}^{-1}$ in Sweden (Bütler et al. 2004). In our study, snag basal area increased in the RES transect from 0.4 in 1999-2001 to $1.9 \mathrm{~m}^{2} \mathrm{ha}^{-1}$ in 2007-2009, but decreased from 0.5 to $0.2 \mathrm{~m}^{2}$ in the MAN transect (Table 3). It was also shown by Wesołowski et al. (2005) that "sanitary" logging, deliberate removal of dying and dead spruces from the forest, negatively affected the distribution of the Three-toed Woodpecker in part of Białowieża National Park.

Bütler et al. (2004) suggested that the volume of dead wood in managed forests in Sweden is too low to sustain Three-toed Woodpeckers in the long-term. The amount of dead wood in managed stands of the Białowieża Forest in comparison to Swedish forests (Fridman and Walheim 2000) is even lower and thus the viability of a long-term sustainable population of the Three-toed Woodpecker in the whole Białowieża Fortest is uncertain. The BNP area is too small to assure the long-term survival of the Białowieża Forest population (Wesołowski et al. 2005). For the existence of the Three-toed Woodpecker, at least $5 \%$ of dead standing trees in older forests should be left; this corresponds to a basal area of c.1.3 $\mathrm{m}^{2}$ ha $^{-1}$ (Bütler et al. 2004). In the Białowieża Forest only BNP (in both study periods) and the RES transect (in the second study period) provided these values. Tree stands of Białowieża Forest outside the national park are poor in dead wood resources. Only the ban on so called "sanitary cutting" in nature reserves of the Białowieża Forest by the Polish authorities in 2008 helped to rebuild dead wood resources in these reserves. However, this is not a permanent law.

The average volume of fallen logs in managed productive forest land in Sweden was estimated to be $2.1-7.7 \mathrm{~m}^{3} \mathrm{ha}^{-1}$, and the highest volumes (c.9.3 $\mathrm{m}^{3} \mathrm{ha}^{-1}$ ) were found in spruce forests in the north (Fridman and Walheim 2000). Much smaller volumes of fallen logs were found in the managed stands of Białowieża Forest (MAN) in the last years of our study $\left(1.4 \mathrm{~m}^{3} \mathrm{ha}^{-1}\right)$ and slightly more in the nature reserve (RES) in the second period (11.5 $\mathrm{m}^{3} \mathrm{ha}^{-1}$ ) compared to the volumes in the BNP (Table 3). In Swedish forests, 73\% of the total dead wood volume consisted of logs and $27 \%$ of snags (Fridman and Walheim 2000). We did not measure the volume of snags, but if we compare the density of snags and logs in all transects their proportion was c.1 : 1 . Snags are usually on average larger than fallen dead trees (Nilsson et al. 2002). In deciduous managed stands of the Białowieża Forest, the total volume per hectare was larger for snags than for logs (Czeszczewik and Walankiewicz 2006). However, in the primeval stands of the Białowieża National Park (Bobiec 2002, Czeszczewik 2009b) there was a larger volume of logs than snags.

The nature reserve where the RES transect was located was established in 1921 as BNP, however, dead wood resources are much lower there (in the first study period the amount of dead wood in RES was similar to that recorded in MAN transect). Some increase in dead wood was recorded after 2008 (Figure 2), but this is still not enough to meet the needs of woodpeckers. We should keep in mind that dead wood removal practices lasted for more than 80 years. The nature conservation policy formerly applied in Polish forest nature reserves (dead wood removal) was not adequate to fully maintain biodiversity. As a result, with respect to the amount of dead wood, protected stands in forest reserves do not differ much from commercially managed stands. We consider that only the strictest forms of conservation as a national park or reserves where dead wood is not removed for a long time are sufficient to preserve the most valuable parts of the Białowieża Forest.

So, based on the above results, we recommend that the management regulations in nature reserves be changed. In coniferous reserves, it would be best to leave at least $2 \mathrm{~m}^{2} \mathrm{ha}^{-1}$ (basal area) of freshly killed spruce after each bark beetle outbreak. Such outbreaks occur every several to 
10 years or so in Białowieża Forest. Coniferous trees can stay as snags for a relatively long time, but are only valuable for some woodpecker species, e.g. White-backed Woodpecker, when in the later stages of deterioration (Czeszczewik 2009a). However, the Three-toed Woodpecker, which is a focal species (Angelstam et al. 2003), requires freshly dead or dying spruce (Amcoff and Eriksson 1996). Forestry practices of removal of infested trees to draw the beetles away from healthy trees, as commonly applied in nature reserves and some national parks, can also destroy the habitats of other species threatened by forestry and lower forest biodiversity.

\section{Acknowledgements}

We heartily thank our many students for their help in tree stand measurements. Shelley A. Hinsley kindly checked the English. The kind co-operation of the Białowieża National Park administration and Polish State Forestry (Nadleśnictwo Białowieża) are acknowledged as well. The study was financed by a grant from the Polish Committee of Sciences (no. 6Po4Go5316), Siedlce University and Polish NGO "Pracownia na rzecz Wszystkich Istot" in Białystok.

\section{References}

Amcoff, M., and Eriksson, P. (1996) Occurrence of three-toed woodpecker Picoides tridactylus at the scales of forest stand and landscape. Ornis Svecica 6: 107-119. (In Swedish with English abstract).

Angelstam, P. K., Bütler, R., Lazdinis, M., Mikusiński, G. and Roberge, J.-M. (2003) Habitat thresholds for focal species at multiple scales and forest biodiversity conservation - dead wood as an example. Ann. Zool. Fennici 40: 473-482.

Bobiec, A. (2002) Living stands and dead wood in the Białowieża forest: suggestions for restoration management. Forest Ecol. Manag. 165: 125-140.

Bobiec, A. (ed.), Gutowski, J. M., Zub, K., Pawlaczyk, P. and Laudenslayes, W. F. (2005) The afterlife of a tree. Warszawa Hajnówka: WWF-Poland.

Bütler, R. Angelstam, P., Ekelund, P. and Schlaepfer, R. (2004) Dead wood threshold values for the three-toed woodpecker presence in boreal and sub-Alpine forest. Biol. Conserv. 119: 305-318.

Czeszczewik, D. (2009a) Foraging behaviour of White-backed Woodpeckers Dendrocopos leucotos in a primeval forest (Białowieża National Park, NE Poland): dependence on habitat resources and season. Acta Ornithol. 44: 109-118.

Czeszczewik, D. (2009b) Marginal differences between random plots and plots used by foraging White-backed Woodpeckers demonstrates supreme primeval quality of the Białowieża National Park, Poland. Ornis Fennica 86: 30-37.

Czeszczewik, D. and Walankiewicz, W. (2006) Logging and distribution of the Whitebacked Woodpecker Dendrocopos leucotos in the Białowieża Forest. Ann. Zool. Fennici 43: 221-227.

Czeszczewik, D., Walankiewicz, W. and Nowak, D. (2009) [White-backed Woodpecker Dendrocopos leucotos.] Pp. 539-544 in P. Chylarecki, A. Sikora and Z. Cenian, eds. Monitoring ptaków lęgowych. Poradnik metodyczny dotyczacy gatunków chronionych Dyrektywa Ptasia. Warszawa: GIOŚ. (In Polish).

Faliński, J. B. (1986) Vegetation dynamics in temperate zone lowland primeval forests: Ecological studies in Bialowieza Forest. Dordrecht, Holland: Dr W. Junk. Publ.

Fridman, J. and Walheim, M. (2000) Amount, structure, and dynamics of dead wood on managed forestland in Sweden. Forest Ecol. Manag. 131: 23-36.

Jönsson, M. T. and Jonsson, B. G. (2007) Assessing coarse woody debris in Swedish woodland key habitats: Implications for conservation and management. Forest Ecol. Manag. 242: 363-373.

Michalek, K. G. and Miettinen, J. (2003) Dendrocopus major Great Spotted Woodpecker. BWP Update 5: 101-184. 
Nilsson, S. G., Niklasson, M., Hedin, J., Aronsson, G., Gutowski, J. M., Linder, P., Ljungberg, H., Mikusiński, G. and Ranius, T. (2002) Densities of large living and dead trees in old-growth temperate and boreal forests. Forest Ecol. Manag. 161: 189-204.

Ohlson, M., Söderström, L., Hörnberg, G., Zackrisson, O. and Hermansson, J. (1997) Habitat qualities versus long-term continuity as determinants of biodiversity in boreal old-growth swamp forest. Biol. Conserv. 81: 221-231.

Pechacek, P. (2006) Foraging behavior of Eurasian Three-toed Woodpeckers (Picoides tridactylus alpinus) in relation to sex and season in Germany. Auk 123: 235-246.

Roberge, J.-M. and Angelstam, P. (2006) Indicator species among resident forest birds - A cross-regional evaluation in northern Europe. Biol. Conserv. 130: 134-147.

Roberge, J.-M., Angelstam, P. and Villard, M. A. (2008) Specialised woodpeckers and naturalness in hemiboreal forests - Deriving quantitative targets for conservation planning. Biol. Conserv. 141: 997-1012.

Solonen, T. and Jokimäki, J. (2010) The efficiency of three-visit square surveys vs. one-visit line transects in censusing sparcely distributed birds in managed forest landscapes. Bird Conserv. Internatn. 21: 156-171.

Walankiewicz, W., Czeszczewik, D. and Nowak, D. (2009) [Three-toed Woodpecker Picoides tridactylus.] Pp. 545-551 in P. Chylarecki, A. Sikora and Z. Cenian, eds. Monitoring ptaków lęgowych. Poradnik metodyczny dotyczacy gatunków chronionych Dyrektywa Ptasia. Warszawa: GIOŚ. (In Polish).

Walankiewicz, W., Czeszczewik, D., Mitrus, C. and Bida, E. (2002) Snag importance for woodpeckers in deciduous stands of the Białowieża Forest. Notatki Orn. 43: 61-71. (In Polish with English summary).

Walankiewicz, W., Czeszczewik, D., Tumiel, T. and Stański, T. (2011) Woodpecker abundance in the Białowieża Forest - a comparison between deciduous, strictly pro- tected and managed stands. Ornis Polonica 52: 161-168.

Wesołowski, T. (2005) Virtual conservation: How the European Union is turning a blind eye to its vanishing primeval forests. Conserv. Biol. 19: 1349-1358.

Wesołowski, T. and Tomiałojć, L. (1986) The breeding ecology of woodpeckers in a temperate primaeval forest - preliminary data. Acta Ornithol. 22: 1-22.

Wesołowski, T., Czeszczewik, D. and Rowiński, P. (2005) Effects of forest management on Three-toed Woodpecker Picoides tridactylus distribution in the Białowieża Forest (NE Poland): conservation implications. Acta Ornithol. 40: 53-60.

Wesołowski, T., Czeszczewik, D., Mitrus, C. and Rowiński, P. (2003) Birds of the Białowieża National Park. Notatki Orn. 44: 1-31. (In Polish with English summary).

Wesołowski, T., Mitrus, C., Czeszczewik, D. and Rowiński, P. (2010) Breeding bird dynamics in a primeval temperate forest over 35 years: variation and stability in a changing world. Acta Ornithol. 45: 209-232.

Wesołowski, T., Rowiński, P., Mitrus, C. and Czeszczewik, D. (2006) Breeding bird community of a primeval temperate forest (Białowieża National Park, Poland) at the beginning of the $21^{\text {st }}$ century. Acta Ornithol. 41: 55-70.

Wesołowski, T., Tomiałojć, L., Mitrus, C., Rowiński, P. and Czeszczewik, D. (2002) The breeding bird community of a primaeval temperate forest (Białowieża National Park, Poland) at the end of the $20^{\text {th }}$ century. Acta Ornithol. 37: 27-45.

Whiles, M. R. and Grubaugh, J. W. (1996) Importance of coarse woody debris to southern forest herpetofauna. Pp. 94-100 in J. W. McMinn and D. A. Crossley, Jr., eds. Biodiversity and coarse woody debris in southern forests. Proceedings of the Workshop on Coarse Woody Debris in Southern Forests: Effects on Biodiversity. Washington DC: USDA Forest Service. (General Technical Report SE-94). 
DOROTA CZESZCZEWIK*, WIESŁAW WALANKIEWICZ, TOMASZ STAŃSKI, MUSTAPHA SAHEL, GRZEGORZ BEDNARCZYK

Siedlce University of Natural Sciences and Humanities, Department of Zoology, Prusa 12, o8-11o Siedlce, Poland.

CEZARY MITRUS

Department of Zoology, Rzeszów University, Ćwiklińskiej 2, 35-601 Rzeszów, Poland.

TOMASZ TUMIEL

Towarowa 2a/48, 15-007 Białystok, Poland.

*Author for correspondence; e-mail:dorotacz@uph.edu.pl

Received 20 January 2012; revision accepted 8 May 2012;

Published online 9 August 2012 